\title{
A new species of the genus Brachycoleus (Hemiptera: Miridae), with a revised identification key to the species found in Iran
}

\author{
Reza HOSSEINI \& Saadi MOHAMMADI \\ Department of Plant Protection, Faculty of Agricultural Sciences, University of Guilan, Rasht, Iran, P.O. Box: 41635-1314; \\ e-mails: rhosseini@guilan.ac.ir, r_hosseini@yahoo.com
}

Accepted:
$4^{\text {th }}$ February 2019
Published online:
$14^{\text {th }}$ February 2019

\begin{abstract}
A new species, Brachycoleus medes sp. nov. (Miridae: Mirinae: Mirini), is described from Kurdistan province, Iran. A revised taxonomic key to the Iranian species of Brachycoleus Fieber, 1858, illustrations of male genitalia, male and female habitus photographs of this new taxon and other reported species from Iran are provided. Diagnosis of the new species is based on a comparison with other congeners found in Iran. Presence of Brachycoleus decolor Reuter, 1887 in the fauna of Iran still remains doubtful.
\end{abstract}

Key words. Hemiptera, Heteroptera, Miridae, Mirinae, Mirini, key, new species, taxonomy, Kurdistan, Iran

Zoobank: http://zoobank.org/urn:lsid:zoobank.org:pub:C3C95EA8-6A3B-4DF3-A66B-E7D4CF5C9230

(C) 2019 The Authors. This work is licensed under the Creative Commons Attribution-NonCommercial-NoDerivs 3.0 Licence.

\section{Introduction}

In the Closterotomus Fieber, 1858 complex, species of the genus Brachycoleus Fieber, 1858, are recognized by erect and semi-erect yellowish pubescence. They are large and relatively broad, with head short and wide, frons markedly projecting over clypeus, corium with two distinct veins. Coloration with prevailing red, orange and yellow tinges, black pattern more or less developed. Labium reaching the middle of mesosternum or in B. pilicornis (Poppius, 1912) and B. caucasicus (Poppius, 1912) mesocoxae (RosenzweIG 1997). Nine species of Brachycoleus are known from the Palaearctic Region (KeRZHNer \& Josifov 1999). The Iranian species of this genus were revised by HosseINI (2016). Until now four species were reported from Iran (LINNAVUORI 2007, Hossein 2016, MoHAmmadi et al. 2018) including B. caucasicus, B. lineellus Jakovlev, 1884, B. steini Reuter, 1877, and $B$. thoracicus Puton, 1892 . Occurrence of $B$. decolor Reuter, 1887 in Iran (see AUKEMA et al. 2013, HosSEINI 2016) remains doubtful and should be verified in the future.

In the present study, a new species of Brachycoleus is described based on male and female specimens collected by sweep net in Kurdistan province, western Iran. Habitus photographs of male and female and other diagnostic characters of this new taxon are provided.

\section{Materials and methods}

Examined specimens were collected using sweep net. Twenty dry mounted specimens were examined in this study using a GX stereomicroscope (GT Vision Ltd, Australia). For the study of genitalia, specimens were softened in $70 \%$ ethanol, the male pygophore was removed and kept in $10 \% \mathrm{KOH}$ solution for a few minutes in a warm hot plate. After the $\mathrm{KOH}$ treatment, the pygophore was washed in distilled water and dissected in a drop of glycerol under the stereomicroscope. Lactic acid was used for expansion of endosoma (SCUDDER \& SCHWARTZ 2012). The dissected parameres and endosoma were studied and illustrated using a drawing tube attached to an Olympus microscope. Measurements of specimens were made using a stereomicroscope equipped with an ocular micrometer lens. The following dimensions were measured: body length (head to end of hemelytra from dorsal view), body width, head width across the eyes in dorsal view, height and length of head in lateral view, width of eyes, interocular distance, length of each antennal segment, collar length and width, pronotum length and width, scutellum length (medially from anterior margin to apex) and width (maximum width at anterior margin), length from costal fracture to apex of cuneus. 


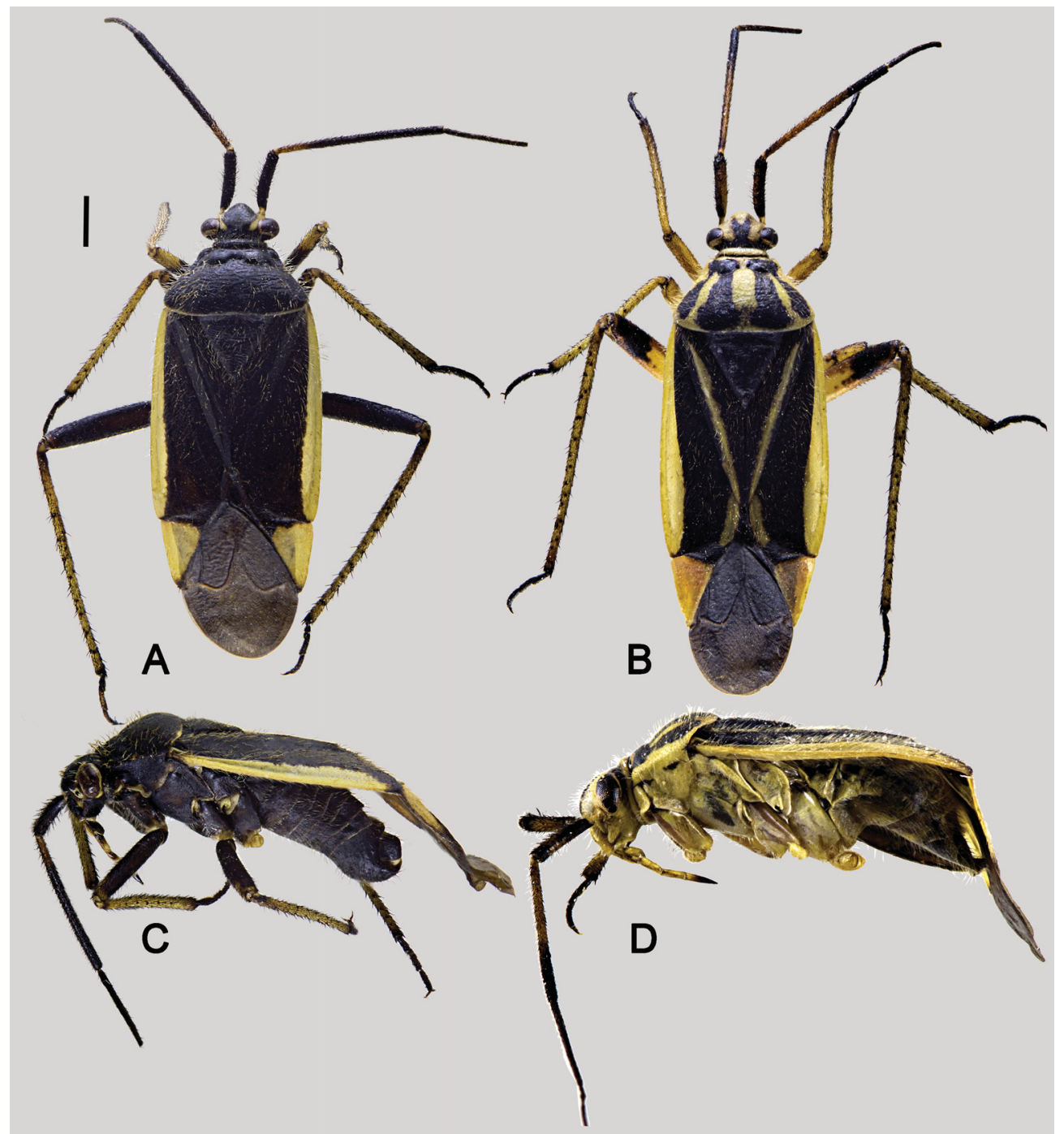

Fig. 1. Habitus photographs of Brachycoleus medes sp. nov. A, C - male; B, D - female. A, B - dorsal view; C, D - lateral view. Scale $=1 \mathrm{~mm}$.

Habitus photographs were taken using a handmade automated imaging system including a Canon EOS 70D DSLR camera equipped with a Canon EF $100 \mathrm{~mm} \mathrm{f} / 2.8$ USM Macro lens attached to a $65 \mathrm{~mm}$ Meike macro extension tube. Partially focused images were combined using Helicon Focus software (http://www.heliconsoft. com). Images were edited using Adobe Photoshop CS3. The nomenclature and terminology of the male genitalia follow those described in KERZHNER \& JOSIFOv (1999) and KonstantinOv (2003), respectively.

\section{Taxonomy}

\section{Brachycoleus medes sp. nov.} (Figs 1-3, Table 1)

Type material. Holotype: IRAN: Kurdistan Province: Sarvabad, Dezli ( $\left.35^{\circ} 21^{\prime} \mathrm{N} 46^{\circ} 10^{\prime} \mathrm{E}, 1806 \mathrm{~m}\right)$, 15.v.2017; S. Mohammadi lgt. ParATYPES ( 7012 우): 4 क 5 우, same data as holotype; 370 우,

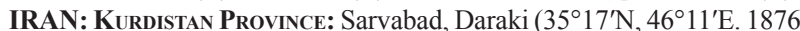
m). 3.vi.2018, S. Mohammadi lgt.. The holotype and most paratypes are deposited in the Natural History Museum of the University of Guilan, Rasht, Iran; two paratypes will be deposited at the Hayk-Mirzayans Insect Museum (HMIM) in Iranian Research Institute of Plant Protection (IRIPP), Tehran, Iran.
Diagnosis. Brachycoleus medes sp. nov. is recognized by the following combination of characters: body elongate-ovoid, mostly black (Fig. 1), pronotum and scutellum uniformly black in males, with orange to stramineous stripe along embolium in both sexes, extending to cuneus, interrupted by a narrow black mark at the cuneus anterior margin. In males, antennomere I black, antennomere II black with proximal quarter indistinctly stramineous (Fig. 1); antennomere I incrassate (Fig. 1), 0.77-0.84× (むう) / $0.71-0.86 \times(q \circ)$ as long as head width, 1.74-1.84× $\left(\delta \delta^{\lambda}\right) / 1.43-1.66 \times(+\circ)$ longer than interocular distance; antennomere II $1.65-2.2 \times(\hat{\delta}) / 2 \times(+q)$ longer than head width; ocular index $1.56-1.80$ in males, $1.87-2.10$ in females; femora black in males.

Description. Male. Coloration. Body mostly black (Fig. 1A). Head: frons, vertex, posterior margin, maxillary plates and clypeus black (Fig. 1C); mandibular plates, margin of eyes on vertex and genae stramineous. Eyes mostly black, marginally stramineous (Figs 1A, C). Antennae: antennomere I uniformly black (Fig. 1A); antennomere II black with proximal quarter indistinctly dark stramineous (Fig. 1A); antennomeres III and IV black. Labium mostly 


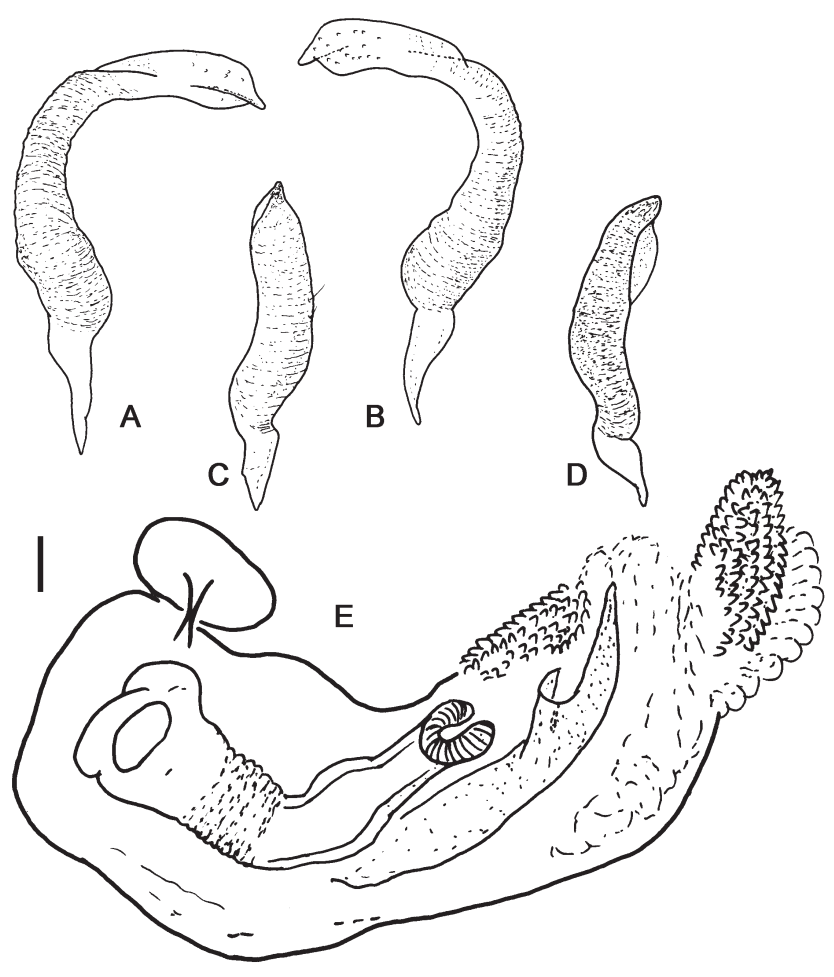

Fig. 2. Genitalia of Brachycoleus medes sp. nov. A, B - left paramere, different views; $\mathrm{C}, \mathrm{D}$ - right paramere, different views; $\mathrm{E}$ - endosoma, lateral view. Scale $=0.1 \mathrm{~mm}$. stramineous, last segment black (Fig. 1C). Pronotum uniformly black, collar black (Fig. 1A). Mesoscutum and scutellum uniformly black (Fig. 1A). Hemelytra mostly black; embolium uniformly stramineous, narrow black mark between embolium and cuneus, cuneus stramineous, sometimes orangish, apical margin of cuneus internally black, membrane fumose (Fig. 1A). Thoracic pleura mostly black, outer margin of propleura stramineous, metathoracic scent gland evaporative area and peritreme stramineous (Fig. 1C). Legs: femora (except apices) and tarsomeres black, apices of femora and tibiae stramineous, in meso- and metatibiae base of spines with black dots (Fig. 1C). Abdomen black, including pygophore (Fig. 1C).

Vestiture. Dorsum covered with erect to semierect hairlike golden setae (Figs. 1A). Antennae covered mostly with semierect hair-like setae, on antennomere I long, on antennomeres II to IV shorter. Thoracic pleura covered with a few semierect hair-like golden setae. Abdomen covered with hair-like setae.

Texture. Body impunctate.

Structure. Body length 8.40-8.72 mm, width 2.84-2.90 $\mathrm{mm}$, robust, elongate-ovoid (Fig. 1A). Head: width of head across eyes $1.28-1.33 \mathrm{~mm}$; interocular distance $0.57-0.60 \mathrm{~mm}$; ocular index 1.56-1.80. Eyes: width 0.35 $\mathrm{mm}$. Antennae: antennomere I incrassate, thicker than other segments, $1.0-1.10 \mathrm{~mm}$ long, $0.77-0.84 \times$ as long as head width, 1.74-1.84× longer than interocular distance; antennomere II slender, antennomeres III and IV narrow and gracile; antennomere II length 2.2-2.93 mm,
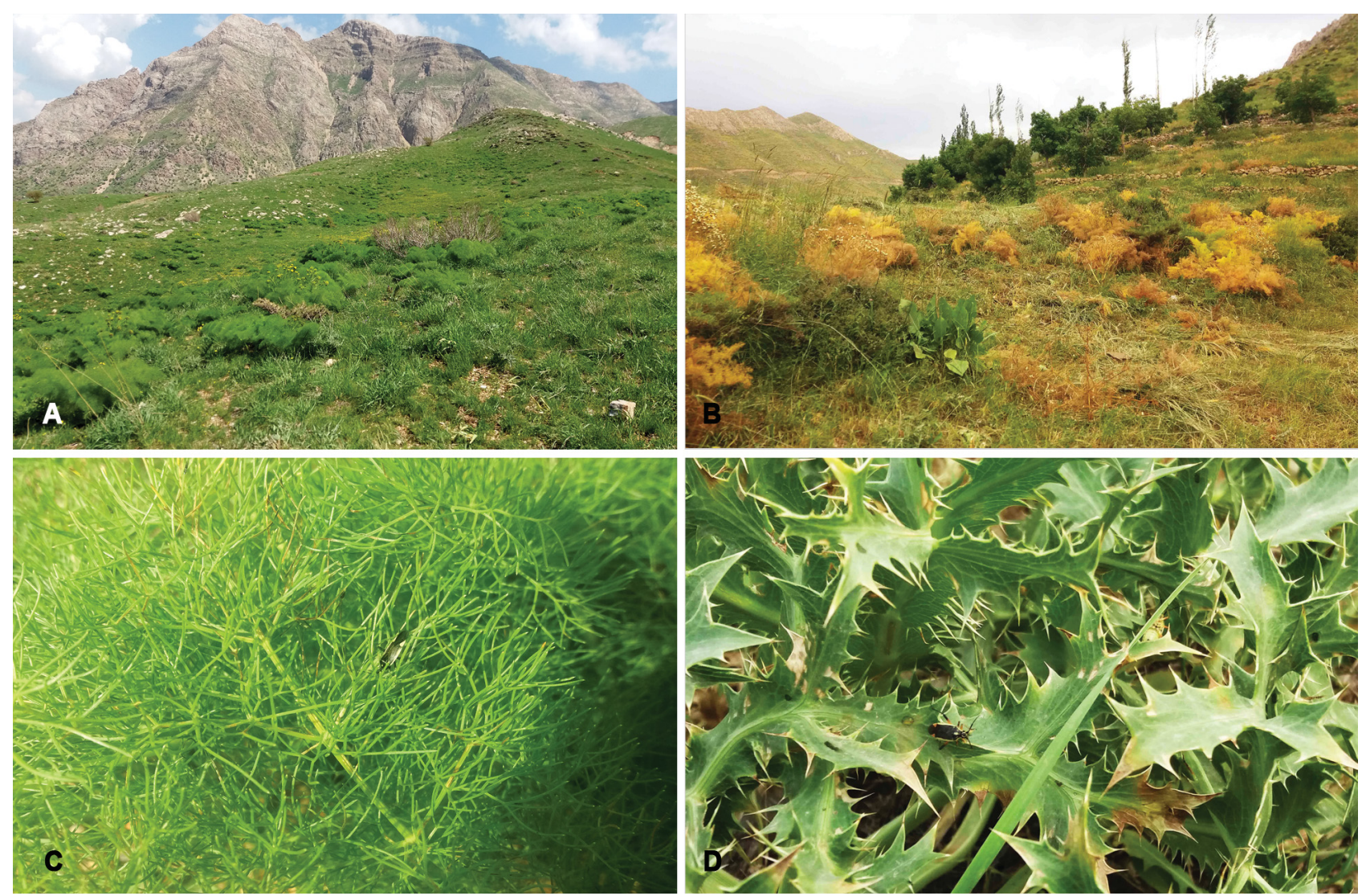

Fig. 3. Natural habitats (A-B) and host plants (C-D) of Brachycoleus medes sp. nov. A - Sarvabad, Dezli $\left(35^{\circ} 21^{\prime} \mathrm{N} 46^{\circ} 10^{\prime} \mathrm{E}, 1806 \mathrm{~m}\right)$; B - Sarvabad, Daraki (35ำ $\left.17^{\prime} \mathrm{N}, 46^{\circ} 11^{\prime} \mathrm{E}, 1876 \mathrm{~m}\right)$; C Prangus ferulacea (L.); D - Eryngium caucasium Trautv. 


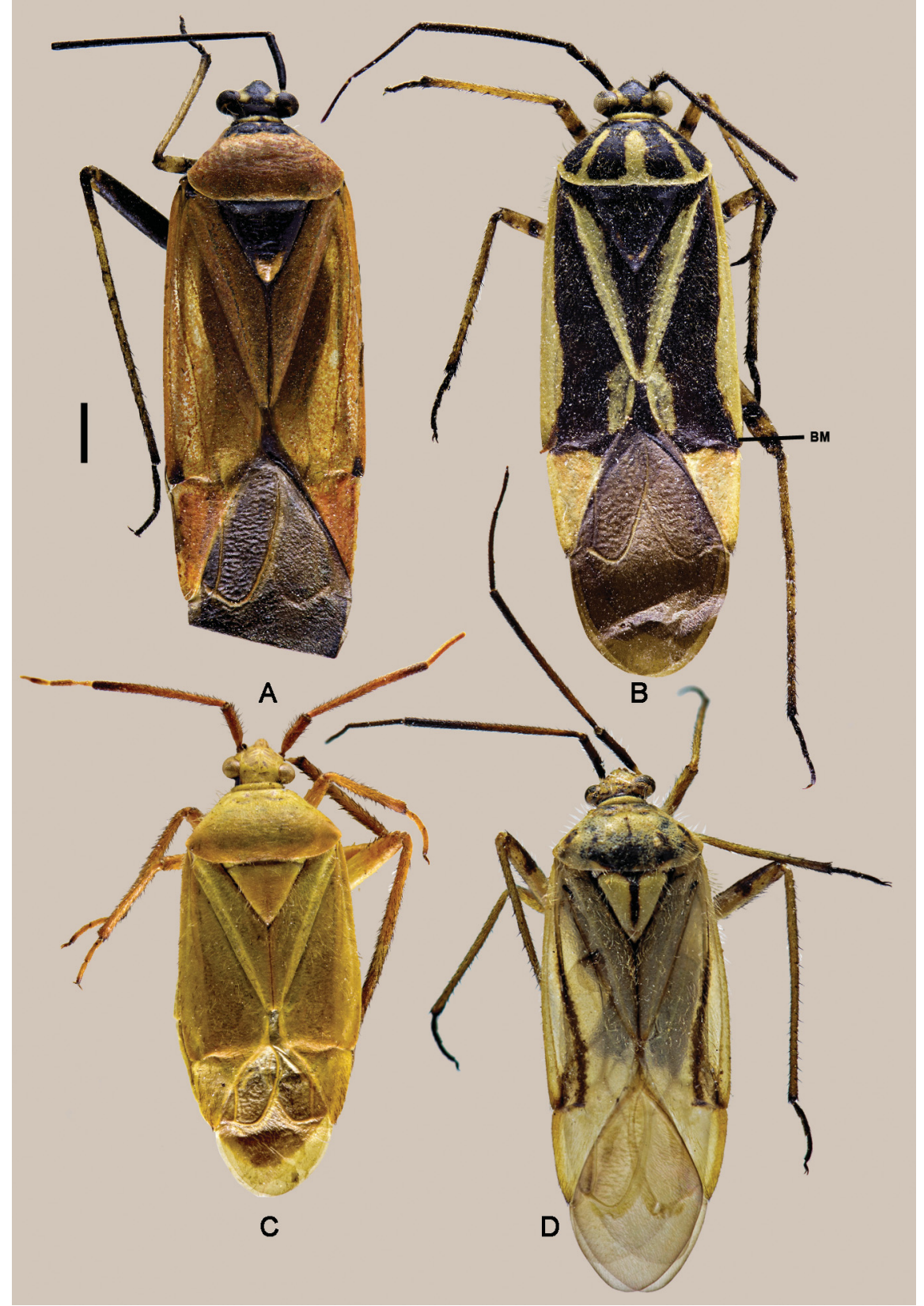

Fig. 4. Dorsal habitus photographs. A - Brachycoleus thoracicus Puton, 1892; B - B. steini Reuter, 1877; C - B. caucasicus (Poppius, 1912); D - B. lineellus Jakovlev, 1884; A, B, $\mathrm{D}$-male; $\mathrm{C}$-female. BM-black mark. (A and D after Moнammadi et al. 2018). Scale $=1 \mathrm{~mm}$.
$1.17-1.65 \times$ longer than head width, $0.90-1.20 \times$ as long as posterior width of pronotum; antennomere III 1.12-1.49 $\mathrm{mm}$ long, antennomere IV $0.90 \mathrm{~mm}$ long. Labium thick and short, reaching middle of mesosternum. Pronotum: callose region distinct, length of pronotum $1.23-1.28 \mathrm{~mm}$, $1.80-1.90 \times$ as long as posterior width of pronotum, anterior width $0.77-0.90 \mathrm{~mm}$, posterior width $2.30-2.45 \mathrm{~mm}$; collar length $0.17-0.20 \mathrm{~mm}$. Scutellum: length $0.98-1.07 \mathrm{~mm}$, anterior width $1.16-1.26 \mathrm{~mm}$, flat, mesoscutum narrowly exposed (Fig. 1A).

Male genitalia. Similar to other species of the genus. Apex of endosoma with well-developed dentate plate. Spiculum present, with reduced process (Fig. 2).

Female. Vestiture, texture and structure mostly as in males, with some exceptions given below.

Colouration. Head: vertex more or less with V-shaped black mark, posterior margin of vertex black, rest of head stramineous (Fig. 1B). Antennae: antennomere I internally brownish stramineous, externally black (Fig. 1B); antennomere II brownish stramineous, distal quarter black (Fig. 1B). Collar mostly stramineous (reddish orange in two paratypes), pronotum with four black longitudinal strips. Calli black, separated from each other, each callus attached to two longitudinal stripes extending almost to posterior margin of pronotum. Scutellum either uniformly black or apically with stramineous mark (Fig. 3). Hemelytra mostly black; embolium uniformly stramineous (reddish orange in two paratypes), clavus with narrow stramineous band along claval suture except basally, cuneus stramineous (reddish orange in two paratypes), sometimes orangish, basal margin black (Fig. 1B). Thoracic pleura mostly stramineous (reddish orange in two paratypes), including evaporative area and peritreme (Fig. 1D) (reddish orange in two paratypes). Legs stramineous, apical quarter of me- 
Table 1. Diagnostic taxonomical characters of Brachycoleus spp. known in Iran. Numbers are ratios or size in mm.

\begin{tabular}{|c|c|c|c|c|c|}
\hline & $\begin{array}{l}\text { B. medes sp.nov } \\
\text { male }(n=8) / \\
\text { female }(n=12)\end{array}$ & $\begin{array}{l}\text { B. thoracicus } \\
\text { male }(\mathrm{n}=4) / \\
\text { female }(\mathrm{n}=2)\end{array}$ & $\begin{array}{l}\text { B. steini } \\
\text { male }(n=2) / \\
\text { female }(n=1)\end{array}$ & $\begin{array}{l}\text { B. lineellus } \\
\text { male }(\mathrm{n}=1) / \\
\text { female }(\mathrm{n}=1)\end{array}$ & $\begin{array}{l}\text { B. caucasicus } \\
\text { female }(\mathrm{n}=1)\end{array}$ \\
\hline Body length & $\begin{array}{l}8.40-8.72 / \\
8.51-9.13 \\
\end{array}$ & $\begin{array}{c}10.03-10.86 / \\
9.17-10.06 \\
\end{array}$ & $\begin{array}{c}9.90-10.24 / \\
8.58 \\
\end{array}$ & $\begin{array}{c}9.44 / \\
8.0 \\
\end{array}$ & 7.43 \\
\hline Body width & $\begin{array}{c}2.84-2.90 / \\
3.09-3.44 \\
\end{array}$ & $\begin{array}{c}3.21-3.66 / \\
3.40-3.46 \\
\end{array}$ & $\begin{array}{c}3.18-3.55 / \\
3.30 \\
\end{array}$ & $\begin{array}{c}3.20 / \\
2.98 \\
\end{array}$ & 2.98 \\
\hline Antennomere I & $\begin{array}{c}1.0-1.1 / \\
0.98-1.20 \\
\end{array}$ & $\begin{array}{c}1.05-1.17 / \\
?\end{array}$ & $\begin{array}{c}0.96-1.0 / \\
0.87\end{array}$ & $\begin{array}{c}0.94 / \\
0.84 \\
\end{array}$ & 0.71 \\
\hline Antennomere II & $\begin{array}{c}2.20-2.93 / \\
2.61-2.86 \\
\end{array}$ & $?$ & $\begin{array}{c}2.7-3.1 / \\
2.38\end{array}$ & $\begin{array}{c}2.98 / \\
2.50 \\
\end{array}$ & 2.31 \\
\hline Antennomere III & $\begin{array}{c}1.12-1.49 / \\
1.23-1.49\end{array}$ & $?$ & $\begin{array}{c}1.35-1.67 / \\
1.28\end{array}$ & $\begin{array}{c}1.37 / \\
1.19 \\
\end{array}$ & 0.94 \\
\hline Antennomere IV & $\begin{array}{c}0.90 / \\
0.88 \\
\end{array}$ & $?$ & $\begin{array}{c}0.89-0.96 / \\
0.90\end{array}$ & $\begin{array}{c}0.80 / \\
0.96 \\
\end{array}$ & 0.59 \\
\hline $\begin{array}{l}\text { Width of head across the eyes } \\
\text { in dorsal view }\end{array}$ & $\begin{array}{c}1.28-1.33 / \\
1.37-1.42 \\
\end{array}$ & $\begin{array}{c}1.28-1.37 / \\
1.40\end{array}$ & $\begin{array}{c}1.26-1.37 / \\
1.35\end{array}$ & $\begin{array}{c}1.26 / \\
1.28 \\
\end{array}$ & 1.19 \\
\hline Interocular distance & $\begin{array}{c}0.57-0.60 / \\
0.68-0.73 \\
\end{array}$ & $\begin{array}{c}0.52-0.57 / \\
0.71\end{array}$ & $\begin{array}{c}0.55-0.66 / \\
0.68\end{array}$ & $\begin{array}{c}0.57 / \\
0.64 \\
\end{array}$ & 0.64 \\
\hline Width of eye & $\begin{array}{c}0.35 / \\
0.34-0.36 \\
\end{array}$ & $\begin{array}{c}0.36-0.38 / \\
0.35\end{array}$ & $\begin{array}{c}0.36-0.40 / \\
0.32\end{array}$ & $\begin{array}{c}0.34 / \\
0.32\end{array}$ & 0.27 \\
\hline $\begin{array}{l}\text { Collar (anterior width of pro- } \\
\text { notum) }\end{array}$ & $\begin{array}{c}0.77-0.90 / \\
0.96-1.05\end{array}$ & $\begin{array}{c}0.82-0.91 / \\
0.98-1.03\end{array}$ & $\begin{array}{l}0.77-0.86 / \\
0.94\end{array}$ & $\begin{array}{c}0.87 / \\
0.91\end{array}$ & 0.82 \\
\hline Collar length (in the middle) & $\begin{array}{c}0.17-0.20 / \\
0.18-0.20\end{array}$ & $\begin{array}{c}0.11-0.16 / \\
0.20\end{array}$ & $\begin{array}{c}0.11-0.13 / \\
0.13\end{array}$ & $\begin{array}{c}0.16 / \\
0.14\end{array}$ & 0.12 \\
\hline $\begin{array}{l}\text { Length of pronotum (from collar } \\
\text { to prosterior margin of pronotum) }\end{array}$ & $\begin{array}{c}1.23-1.28 / \\
1.26-1.49\end{array}$ & $\begin{array}{c}1.26-1.37 / \\
1.46\end{array}$ & $\begin{array}{c}1.23-1.26 / \\
1.16\end{array}$ & $\begin{array}{l}1.23 / \\
1.14\end{array}$ & 1.23 \\
\hline Posterior width of pronotum & $\begin{array}{c}2.30-2.45 / \\
2.54-2.77 \\
\end{array}$ & $\begin{array}{c}2.60-2.75 / \\
2.80-2.88 \\
\end{array}$ & $\begin{array}{l}2.60-2.75 / \\
2.77\end{array}$ & $\begin{array}{c}2.68 / \\
2.52 \\
\end{array}$ & 2.54 \\
\hline Ocular index & $\begin{array}{c}1.56-1.80 / \\
1.87-2.13 \\
\end{array}$ & $\begin{array}{c}1.43-1.51 / \\
2.0\end{array}$ & $\begin{array}{c}1.50-1.65 / \\
2.14 \\
\end{array}$ & $\begin{array}{c}1.66 / \\
2.0 \\
\end{array}$ & 2.33 \\
\hline $\begin{array}{l}\text { Antennomere I / interocular } \\
\text { distance }\end{array}$ & $\begin{array}{c}1.74-1.84 / \\
1.43-1.66 \\
\end{array}$ & $\begin{array}{c}1.84-2.22 / \\
?\end{array}$ & $\begin{array}{c}1.50-1.75 / \\
1.26\end{array}$ & $\begin{array}{c}1.64 / \\
1.32 \\
\end{array}$ & 1.1 \\
\hline $\begin{array}{l}\text { Ratio antennomere I length / head } \\
\text { width }\end{array}$ & $\begin{array}{c}0.77-0.84 / \\
0.70-0.86 \\
\end{array}$ & $\begin{array}{c}0.77-0.91 / \\
?\end{array}$ & $\begin{array}{c}0.73-0.76 / \\
0.64\end{array}$ & $\begin{array}{c}0.74 / \\
0.66 \\
\end{array}$ & 0.59 \\
\hline $\begin{array}{l}\text { Ratio antennomere II length / head } \\
\text { width }\end{array}$ & $\begin{array}{c}1.17-1.65 / \\
1.90-2.04 \\
\end{array}$ & $\begin{array}{c}2.39-2.61 / \\
?\end{array}$ & $\begin{array}{c}2.14-2.26 / \\
1.76\end{array}$ & $\begin{array}{c}2.36 / \\
1.96 \\
\end{array}$ & 1.94 \\
\hline $\begin{array}{l}\text { Ratio antennomere II / posterior } \\
\text { width of pronotum }\end{array}$ & $\begin{array}{c}0.90-1.20 / \\
1.0-1.04 \\
\end{array}$ & $\begin{array}{c}1.22-1.35 / \\
?\end{array}$ & $\begin{array}{c}1.0-1.10 / \\
0.85\end{array}$ & $\begin{array}{c}1.1 / \\
1.0 \\
\end{array}$ & 0.90 \\
\hline pronotum width / length & $\begin{array}{c}1.87-1.94 / \\
1.84-2.14 \\
\end{array}$ & $\begin{array}{c}1.93-2.12 / \\
1.90-1.96\end{array}$ & $\begin{array}{c}2.11-2.18 / \\
2.37\end{array}$ & $\begin{array}{c}2.16 / \\
2.20 \\
\end{array}$ & 2.05 \\
\hline Anterior width of scutellum & $\begin{array}{c}1.16-1.26 / \\
1.30-1.49\end{array}$ & $\begin{array}{c}1.26-1.33 / \\
1.40-1.43\end{array}$ & $\begin{array}{c}1.23-1.42 / \\
1.42\end{array}$ & $\begin{array}{c}1.33 / \\
1.19 \\
\end{array}$ & 1.26 \\
\hline Scutellum length & $\begin{array}{c}0.98-1.07 / \\
1.05-1.20\end{array}$ & $\begin{array}{c}1.14-1.28 / \\
1.23-1.26 \\
\end{array}$ & $\begin{array}{c}1.14-1.26 / \\
1.14\end{array}$ & $\begin{array}{c}1.16 / \\
1.03 \\
\end{array}$ & 1.0 \\
\hline Length of head in lateral view & $\begin{array}{c}0.59-0.68 / \\
0.73-0.77\end{array}$ & $\begin{array}{c}0.57-0.68 / \\
0.68-0.70\end{array}$ & $\begin{array}{c}0.50 / \\
0.64 \\
\end{array}$ & $\begin{array}{c}0.57 / \\
0.61 \\
\end{array}$ & 0.82 \\
\hline Height of head in lateral view & $\begin{array}{l}1.0-1.12 / \\
1.10-1.26 \\
\end{array}$ & $\begin{array}{l}1.0-1.07 / \\
1.12-1.20 \\
\end{array}$ & $\begin{array}{c}0.96-1.0 / \\
1.12\end{array}$ & $\begin{array}{l}1.0 / \\
1.05 \\
\end{array}$ & 0.80 \\
\hline Ratio of antennomere I /II lenghts & $\begin{array}{l}2.0-2.79 / \\
2.35-2.65 \\
\end{array}$ & $2.78-3.34$ & $\begin{array}{c}2.8-3.1 / \\
2.73 \\
\end{array}$ & $\begin{array}{c}3.17 / \\
2.97 \\
\end{array}$ & 3.25 \\
\hline
\end{tabular}

tafemora black (femora reddish orange in two paratypes). Abdomen stramineous (reddish orange in two paratypes), each abdominal segment dorsolaterally with black marks.

Structure. Body length 8.51-9.13 mm. Head: width across eyes $1.37-1.42 \mathrm{~mm}$; interocular distance $0.68-0.73$ mm. Eyes: width 0.34-0.36 mm; ocular index 1.87-2.13. Antennae: antennomere I 0.98-1.20 mm long, 0.71-0.86× as long as head width, 1.43-1.66× longer than interocular distance; antennomere II 2.61-2.86 mm long, 1.90-2.04× longer than head width, 1.0-1.04× posterior width of pronotum; antennomere III 1.23-1.49 mm long; antennomere IV $0.88 \mathrm{~mm}$ long. Pronotum: length $1.26-1.49 \mathrm{~mm}$, $1.84-2.14 \times$ as long as posterior width; posterior width 2.54-2.77 mm; collar length $0.18-0.20 \mathrm{~mm}$; anterior width 0.96-1.05 mm. Scutellum: length 1.05-1.2 mm, anterior width 1.3-1.49 mm. Female genitalia were not dissected in this study due to the poor condition of the female specimens.

Differential diagnosis. Brachycoleus medes sp. nov., compared to other species of Brachycoleus recorded in Iran, 


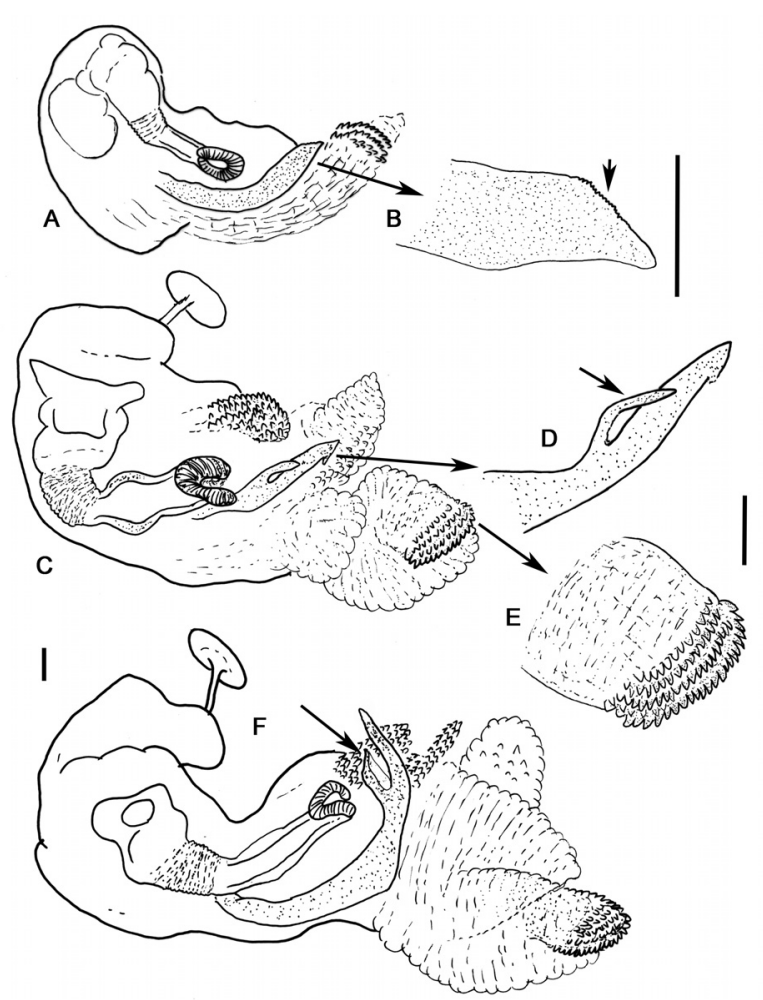

Fig. 5. Male genitalia. A - Brachycoleus lineellus Jakovlev, 1884; B spiculum; C - B. steini Reuter, 1877; D - spiculum; E - dentate plate; $\mathrm{F}-$ B. thoracicus Puton, 1892. Scale $=0.1 \mathrm{~mm}$.

is darker (Fig. 4). Its males are easily recognized by their unique coloration, with pronotum and scutellum uniformly black, except for an orange to stramineous stripe along embolium, extending to cuneus (Fig. 1). Similarities can be noticed between females of $B$. medes and B. steini in colour pattern, although in $B$. steini there is a continuous transverse black mark on callose region, both stramineous bands of clavus along claval suture and black mark between embolium and cuneus are wider.

Male genitalia exhibit only minor differences compared to other species of the genus. Endosoma in B. lineellus is smaller than in other species of the genus, process in spiculum absent, basal half of its apex serrate (Figs 5A, B), in B. steini with a narrow process in spiculum, apex of spiculum almost hook-shaped (Figs 5C-E), in B. thoracicus process of spiculum is more developed and spiculum apically simple (Fig. 5F), in B. medes process of spiculum is reduced and far from the apex (Fig. 2E).

The dorsal pattern of $B$. decolor Reuter, 1887 is relatively variable (STICHEL 1930 inferred from $\mathrm{ScHuH}$ 2013); however, according to RosenZweIG's (1997) and WAGNER's (1974) figures of endosoma, B. decolor has an additional sclerite in the lateral lobe or on the other hand two spicula. Male genitalia of $B$. pilicornis (Panzer, 1805) and B. decolor Reuter, 1887 are depicted in Fig. 6. (Rosenzweig 1997).

Brachycoleus medes sp. nov. can be separated from other Iranian Brachycoleus species using the key below.

Etymology. The species is named after "the Medes", an ancient Iranian people who lived in north-western Iran known as Media region; noun in apposition.

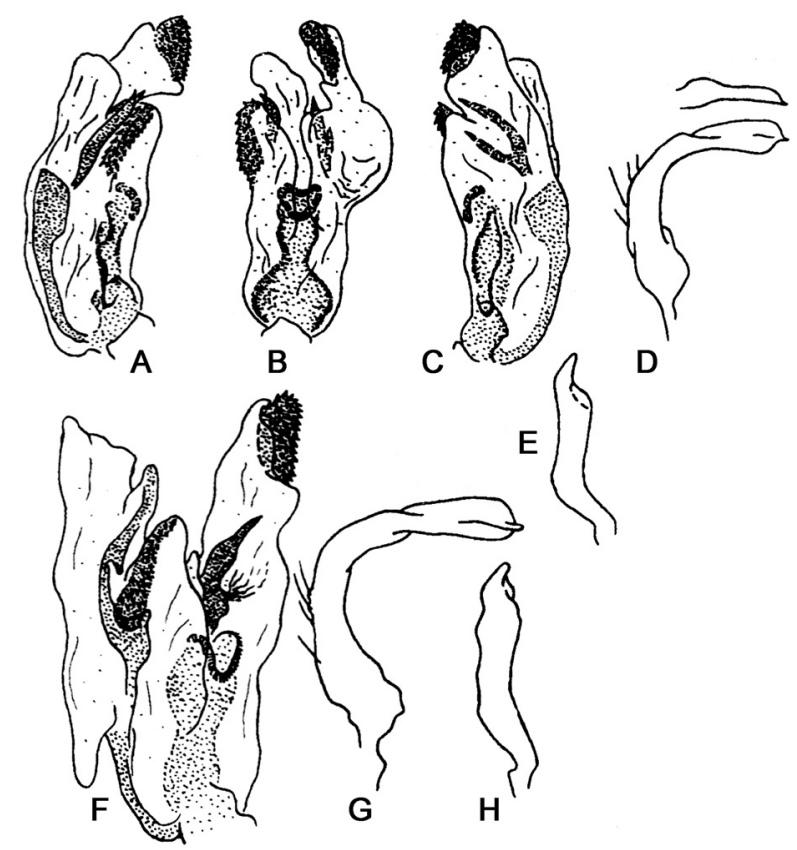

Fig. 6. Male genitalia. A-E - Brachycoleus pilicornis (Panzer, 1805); F-H - B. decolor Reuter, 1887; A, B, C, F - endosome different views; $\mathrm{D}, \mathrm{G}$ - left paramere; E, H - right paramere (after RosenzWEIG 1997).

Collection circumstances. The species was collected by sweep net on Prangus ferulacea (L.) (Fig. 3C) and Eryngium caucasium Trautv. (Fig. 3D) (Apiaceae) in hilly slopes (Figs 3 A, B).

Distribution. Iran (Kurdistan province).

\section{Key to males of the Iranian species of Brachycoleus \\ (modified from Hosseini 2016).}

1 Body color in dorsal view mostly black, pronotum and scutellum uniformly black, length from costal fracture to apex of cuneus $1.42 \mathrm{~mm}$, ocular index 1.56-1.80 in $\widehat{\sigma}(1.48 \mathrm{~mm}$ and $1.87-2.13$ respectively in $\uparrow)$.

B. medes sp. nov.

- Body color in dorsal view variable, other characters different.

2 Body color in dorsal view red or orange, pronotum red, calli and scutellum black, sometimes posteriorly red or orange. Antennomere II $>2.5 \times$ as long as width of head, length from costal fracture to apex of cuneus $2.0 \mathrm{~mm}$ in male, $1.66 \mathrm{~mm}$ in female, ocular index $1.43-1.51$ in male, 2.0 in female.

B. thoracicus Puton, 1892

- Body color in dorsal view greenish or stramineous. Scutellum not black like in previous species. Antennomere II $<2 \times$ width of head.

3 Pronotum and hemelytra without distinct black marks. Ocular index $0.80-0.82$ in $\delta$ (2.33 in 9 ). Antennomere I $0.65-0.69 \times$ as long as width of head, antennomere II $1.5 \times$ as long as posterior width of pronotum. Length from costal fracture to apex of cuneus $1.22 \mathrm{~mm}$ in 9 . B. caucasicus (Poppius, 1912)

- Pronotum and hemelytra with distinct black marks. ... 4 
4 Pronotum bright, with 1 to 3 small and narrow dark longitudinal stripes. Corium pale, each with only narrow dark longitudinal stripes on commissure and medial flexion line, length from costal fracture to apex of cuneus $1.71 \mathrm{~mm}$, ocular index $1.66 \mathrm{in} \hat{\jmath}(1.26 \mathrm{~mm}$ and 2 respectively in + ).

B. lineellus Jakovlev, 1884

- Pronotum with broad dark longitudinal stripes. Corium dark. Other characters variable. ... 5

5 A wide black stripe on corium produced laterad along embolium / cuneus boundary and touching lateral margin of hemelytron (Fig. 4B: BM), hairs of metatibiae almost as long as the spines, apex of cuneus usually black, 2 nd antennal segment about $2.1-2.2 \times$ width of head, length from costal fracture to apex of cuneus $1.82 \mathrm{~mm}$, ocular index $1.5-1.65$ in $\hat{\sigma}(1.42 \mathrm{~mm}$ and 2.14 respectively in $q$ ).

B. steini Reuter, 1877

- A wide black stripe on corium not produced laterad, outer margin of hemelytron completely yellow, hairs of metatibiae shorter than spines, apex of cuneus not black, ocular index approximately 2, endosome with two spicula (WAGNER 1974). [B. decolor Reuter, 1887]

(Known from Europe and Central Asia)

\section{Acknowledgments}

The authors are greatly indebted to Attilio Carapezza (University of Palermo, Palermo, Italy) and Frédéric Chérot (Departement de l'Étude du Milieu naturel et agricole, Service Public de Wallonie, Belgique) for providing many helpful comments on the manuscript and identification of some specimens, and Mozhgan Zamani (PhD Student, University of Guilan) for her assistance in this study.

\section{References}

AUKEMA B., RIEGER CH. \& RABITSCH W. 2013: Catalogue of the Heteroptera of the Palaearctic Region. VI. Supplement. The Netherlands Entomological Society, Amsterdam, xxiii +629 pp.

HOSSEINI R. 2016: A review on the genus Brachycoleus (Hemiptera, Miridae) with identification key to the species found in Iran. Vestnik Zoologii 50: 105-110.

KERZHNER I. M. \& JOSIFOV M. 1999: Family Miridae Hahn, 1833. Pp. 1-576. In: AUKEMA B. \& RIEGER CH. (eds): Catalogue of the Heteroptera of the Palaearctic Region. Vol. 3. Cimicomorpha II. The Netherlands Entomological Society, Amsterdam, xiv +577 pp.

KONSTANTINOV F. V. 2003: Male genitalia in Miridae (Heteroptera) and their significance for supra-generic classification of the family. Part I: general review, Isometopinae and Psallopinae. Belgian Journal of Entomology 5: 3-36.

LINNAVUORI R. E. 2007: Studies on the Miridae (Heteroptera) of Gilan and the adjacent provinces in northern Iran. II. List of species. Acta Entomologica Musei Nationalis Pragae 47: 17-56.

MOHAMMADI S., HOSSEINI R. \& HAJIZADEH J. 2018: First record of Brachycoleus thoracicus Puton, 1892 (Hemiptera, Miridae) from Iran. Acta Entomologica Serbica 23: 19-23.

ROSENZWEIG V. YU. 1997: Revised classification of the Calocoris complex and related genera (Heteroptera: Miridae). Zoosystematica Rossica 6: 139-169.

SCUDDER G. G. E. \& SCHWARTZ M. D. 2012: Two new species of Trigonotylus (Hemiptera: Heteroptera: Miridae: Stenodemini) from western Canada and northwestern United States. Zootaxa 3714: 51-58.

SCHUH R. T. 2013: Online Systematic Catalog of Plant Bugs (Insecta: Heteroptera: Miridae). http://research.amnh.org/pbi/catalog/ (Last access: December 2018).

STICHEL W. 1930: Illustrierte Bestimmungstabellen der Deutschen Wanzen. Fasc. 6-7. W. Stichel, Berlin-Hermsdorf, pp. 147-210.

WAGNER E. 1974: Die Miridae Hahn, 1831, des Mitelmeerraumes und der Makaronesischen Inseln (Hemiptera, Heteroptera). Teil. 1. Entomologische Abhandlungen 37(supplement).: i-iii + 1-484 pp. 
